\title{
HDD 工法におけるバイブロを用いた
}

\section{ドリルビットの三次元位置推定手法の検討}

A Study for Estimating the 3D Location of the Drill-Bit during Horizontal Directional Drilling using "Vibro"

\author{
田村潤平 $*$ ・川村洋平* ・ 持地英美 $* *$ ・佐々木直人 $* *$ 大 大川浩一 *** \\ Junpei Tamura, Youhei Kawamura, Hidemi Mochiji, Naoto Sasaki, and Hirokazu Okawa \\ *筑波大学大学院システム情報工学研究科（†305-8573 茨城県つくば市天王台 1 丁目） \\ **多田建設株式会社（干136-0072 東京都江東区大島 2 丁目） \\ ***秋田大学大学院工学資源学研究科（T010-8502 秋田県秋田市手形学園町）
}

\begin{abstract}
Horizontal directional drilling (HDD) is the method expected to prevail for laying lifelines that avoids the need to make an open cut. However, the location of the drill-bit underground must be known at all times when conducting this method. As conventional electromagnetic wave-based methods are known to have several problems, herein we suggest a new method based on the propagation of elastic waves in the ground. In this study, "Vibro" is used as the generation method of elastic waves. This is a feature loaded on the heavy machineries used for HDD. Differences of arrival time are obtained from first peak times of the waveforms measured by the geophones set up on the ground. The possibility to actualize this method is examined by application of an approximate three-dimensional (3D) location method to the differences. As the result of this study, there is the possibility to actualize this method but accuracy improvement is challenges for the future.
\end{abstract}

Key Words: $H D D, 3 D$ location estimation, difference in arrival time, elastic wave

\section{1 緒言}

近年，都市機能の高速化，高度化に伴い各種ライフラ インの整備手法が重要となっている. 本研究の対象であ る HDD(Horizontal directional drilling)工法（図一-1）とは, 電気，ガス，上下水道，ネットワーク等の各種ライフラ インを非開削(表一1)で敷設することができる工法の一 つであり，交通遮断や排土問題の少ないクリーンで安全 性の高い工法であることから，今後の普及が期待されて
いる. この工法は, 掘削, 拡張, 引き込みの 3 つの作業 工程を有している．初めに，重機からロッドを継ぎ足し ながら(写真一 1$)$, 先端に取り付けられているドリルビッ 卜(写真一2)で地中に埋設管を通すための細い穴を掘削 する. 次に，掘削工程で貫通させた穴を，埋設管の口径 に達するまで徐々に拡張していく，最後に，拡張した穴 に埋設管を引き込み，ライフラインの敷設を行う。しか しながら，上記の工程で意図した位置にライフラインの 埋設を行うためには，最初の工程である掘削を行う際に， 地中のドリルビットの位置を随時計測し，ドリルビット

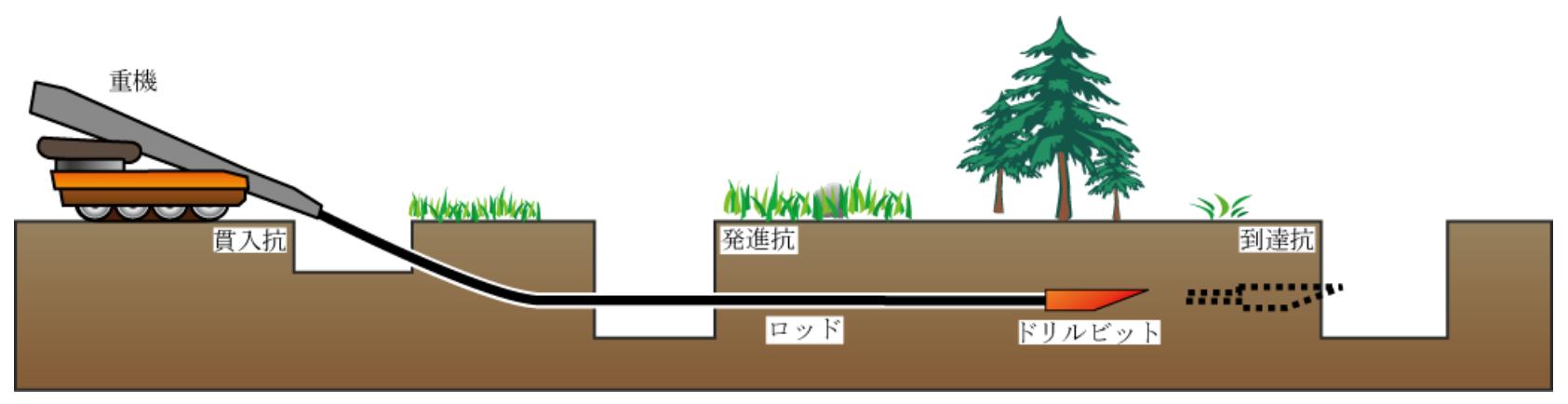

図-1 HDD 工法模式図 


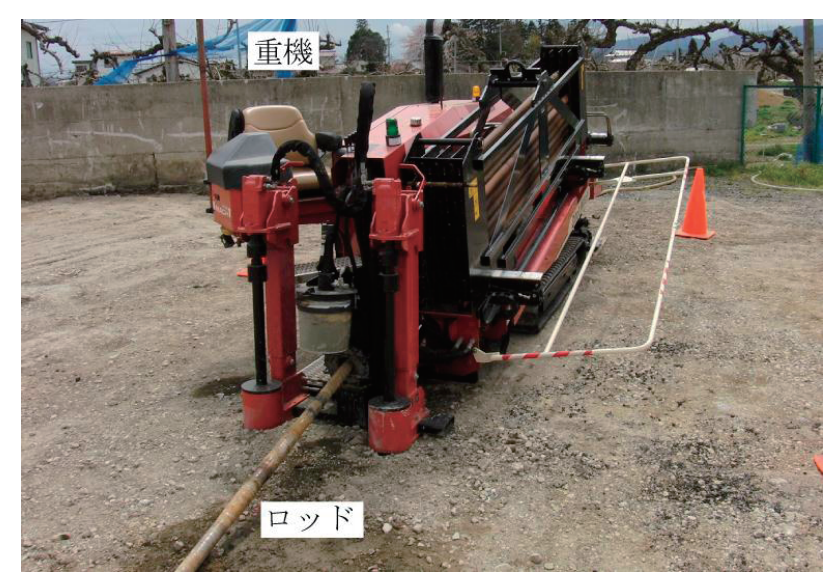

写真－1ＨDD 工法に用いられる重機

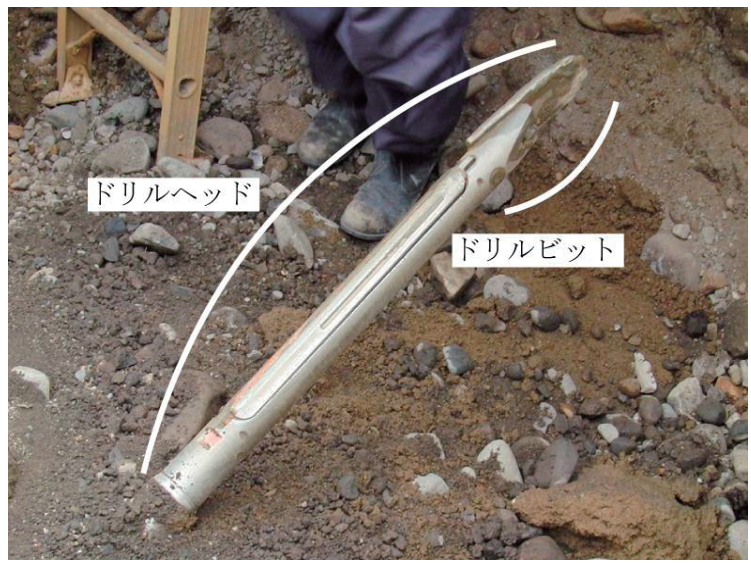

写真一2 ドリル先端部

の進路に修正を加えながら掘削を進めていく必要があ る. そして，そのときの計測精度が，HDD 工法でライ フラインの敷設を行う際の最終的な埋設位置に大きく 影響する．地中のドリルビットの位置を計測するための 手法として, 現在一般的に用いられている手法は電磁波 を利用したものである。しかしながら，この手法では， ドリルビットの真上で計測を行うことが必須である。そ のため, HDD 工法の施工ライン上に建造物がある場合 には，ドリルビットの位置計測を行うことができない. また，電磁波を利用するという特性上，降水があった場 合など土中の含水率が大きく変化している場合や，付近 に鉄塔があるような場合等, 電磁波が周辺の環境から大 きく影響を受けてしまうような状況下においては正確 な計測を行うことができない. そこで，上述の状況にも 対応できる位置計測システムを構築することが，本工法 の更なる普及に繋がると考えられる. そのため，社会的 にも新たな位置計測システムの構築は強く望まれてお り, 本研究の目的はその要望に応える計測システムを構 築することである.

本研究では電磁波に替わる新たな計測手法として，ド リルビットから発生する弾性波による計測手法を提案 した。弾性波を用いた物理探査手法としては反射法 ${ }^{1-9)}$
が一般的であるが，本研究では地中からの弾性波を利用 した位置計測を行うため，直接法による位置計測を試み た. 本実験は，弾性波の入力手法として油圧バイブロ(バ イブロサイス)を用いたものである。これは，HDD 工法 で用いる重機に掘削を進めるための手段の一つとして 予め搭載されている機能であり, 油圧を用いてドリルビ ットに前後運動を生じさせることで, 碟混士のような固 い地盤や帯水砂層など従来の HDD 工法では掘削が困難 な地盤に対しても，HDD 工法の施工を可能にするもの である. 本研究では，バイブロによって生じさせた弾性 波を計測し位置推定を試みることで，弾性波による位置 推定の可能性を検討した。

\section{表-1＼cjkstart主な非開削工法の技術区分}

\begin{tabular}{l|l}
\hline 技術区分 & 備考 \\
\hline 大中口径管推進工法 & 呼び径800以上の推進工法 \\
\hline 小口径管推進工法 & 呼び径700以下の推工迲 \\
\hline 取付管推進工法 & 地中の本管に接続管を推進させる \\
\hline 改築推進工法 & 老朽既設管を新設管に置き換える \\
\hline 誘導式水平ドリル(HDD)工法 & 新設管を地上から引き込む \\
\hline 下水道管渠更生工法 & 老朽下水道管渠を補強更生 \\
\hline ケーシング(小型)立坑工法 & 推進用の円形小型立坑を設置 \\
\hline 非開削特殊工法 & 上記の範疇に入らない特殊工法 \\
\hline
\end{tabular}

\section{2 計測原理}

弾性波を用いた一般的な地中埋設物検知手法として は，地表面から弾性波を入力し，埋設物からの反射波 から位置計測を行う反射法が考えられる. しかしなが ら，今回は地中のドリルビットから弾性波を出力する ことが可能であるため, 直接法による位置計測を行う. 直接法を用いる際には, 地中で弾性波が出力された瞬 間から各ジオフォンに達するまでの時間を計測するこ とで三点測量的な位置推定を行いたいが, HDD 工法に おいてはドリルビットまでロッド内部を通して信号ケ 一ブルを接続することが困難であるため，弾性波の発 生タイミングと同時にトリガをかけることができない. そのため，一般的な三点測量のような位置測定は行う ことができない. そこで，本手法では地表面に展開し たセンサのいずれか 1 つに弾性波が到達した瞬間にト リガをかけ計測を開始し，各ジオフォンへの弾性波の 到達時間差からドリルビットの三次元位置推定を行う。 なお，弾性波には，実体波の他に表面波も混在して計 測されるが，本研究では実体波の到達時間差を利用し て位置推定を行う。

まず，ジオフォンを 2 つ用いた場合について考える. 以降, 2 節では地表面でのドリルビットの進行方向を $y$ 軸, 垂直な方向で右向き正を $x$ 軸とし, 地表面に垂直で 上向き方向を $z$ 軸とする. 図一 2 は, 二つのジオフォン, 及びドリルビットが $x-z$ 平面上にある場合のモデルであ 


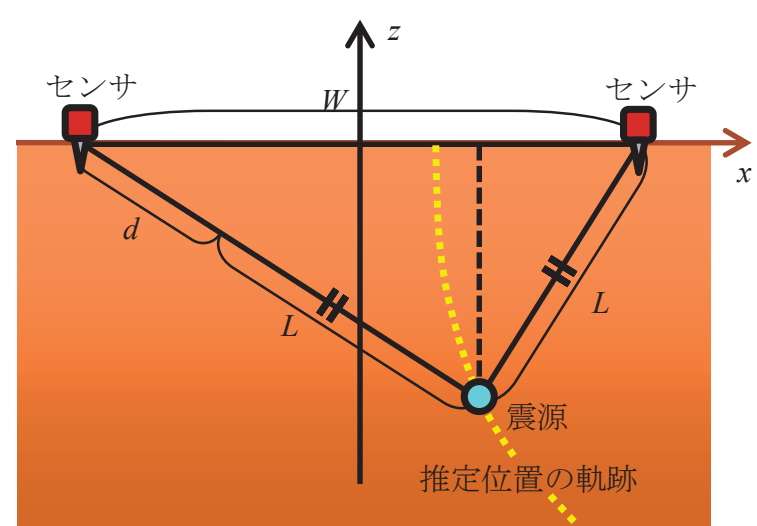

図-2 位置推定モデル

る. 図中の $W$ はセンサ間距離, $d$ はドリルビットまでの 距離差を示しており， $L$ は弾性波の発生タイミングを取 得できないことから生じる未知数である.このモデルで は, 計測現場一帯での層モデルが単一であると仮定し, 弾性波は屈折せずジオフォンまでの最短距離を伝播す るものとする. 2 つのジオフォンではドリルビットの位 置を完全に特定することはできないが, 図一2 より $x, z, d$, $W$ を用いて, 式(1)が示寸軌跡上にドリルビットが存在す ると考えることができる.

$$
z=-\sqrt{\left(W^{2}-d^{2}\right)\left(\frac{x^{2}}{d^{2}}-0.25\right)} \quad \cdots
$$

図一2 中の点線は式(1)の軌跡の概形を示したものであ る.ここで $d$ は 2 つの゙オフォンへの弾性波の到達時間 差 $t$ と弾性波の伝播速度 $v$ の積(式(2))で表すことができ る.

$$
d=v \times t \quad \cdots \cdot(2)
$$

よって，速度は土質によって変化することを考慮する と, 式(1)は $x, z, v$ のつの未知数を持つ関係式と考える ことができる. 次に，ドリルビットが図一2 の平面上に ない場合を考える. 式(1)より，三次元の場合の関係式は $y$ を用いて式(3)で表すことができる.

$$
z=-\sqrt{\left(W^{2}-d^{2}\right)\left(\frac{x^{2}}{d^{2}}-0.25\right)-y^{2}} \cdots
$$

式(1)と同様に，d は式(2)で表されるので，2つのジオ フォンで震源からの弾性波を計測すると, 4 つの未知数 $(x, y, z, v)$ を持つ関係式が得られる. 従って, 実際にド リルビットの位置推定を行う際には，同様の関係式を 4 つ準備し，それらの交点を調べることで震源の位置を特 定することができると考えられる. 以上より，4 つの到 達時間差が得られれば三次元での位置推定が可能であ ると言える.ここで，4 つの到達時間差を得るためには 最低限 5 つのセンサを用いる必要があることに注意する。 これは必要な值が “差” である事に起因寸る.もし, 弾 性波発生のタイミングを取得できるのであれば，その夕 イミングを基準とし差を得れば良いため 4 つのセンサで
位置推定を行うことができる．しかしながら，HDD 工 法を対象とする本研究では基準となるタイミングが取 得できないため, もう一つセンサを用いる必要がある. 以上の理由から, 三次元での位置推定を実現するために は最低限 5 つのジオフォンが必要であることがわかる. しかしながら，実際に弾性波の計測を行い，位置推定を 適用する際には, 地盤中の不確定要素の影響を受けてし まうため, 最低限のセンサ個数である 5 つのジオフォン で位置推定を行うと大きな䛊差を含んでしまう可能性 がある. そこで, 精度向上のためにセンサ個数を増やし て計測する場合, 計測誤差の影響で一つの交点を得るこ とができない. そのため, 本研究ではインバージョン(逆 解析処理)を用いることで位置推定を行った. 具体的なイ ンバージョン手法については 4 節で述べる.

\section{3 バイブロを用いた計測実験}

\section{1 バイブロを用いた計測実験の概要}

本実験では，バイブロを用いて実規模での計測実験を 行った. バイブロは HDD 工法に用いる重機に予㣁わ っている機能の一つであり, 油圧を用いて重機からロッ ドを通してドリルビットに前後運動を生じさせるもの である. 任意波形の出力は行うことはできないが，非常 に強力な弾性波の出力が可能であり, 広範囲での位置推 定が期待される. バイブロの本来の用途は, 従来の HDD 工法では困難であった碩混土のような堅い地盤や帯水 砂層等に対しても，連続的な衝撃を加えることで，掘削 を進めることが可能になるというものである. 今回は, その際の前後運動によって生じる弾性波を利用して位 置推定を試みる. 図一3に実験時のシステム構成を示す. 弾性波の計測には, ジオフォンを使用した. ジオフォン はムービングコイル型の速度計である. 図一4 は使用し たジオフォンの感度に対する周波数特性を示したもの であり, $10 \mathrm{~Hz}$ 以上の周波数に対してフラットな周波数特 性を示している事が読み取れる. また, 図一 5 はバイブ

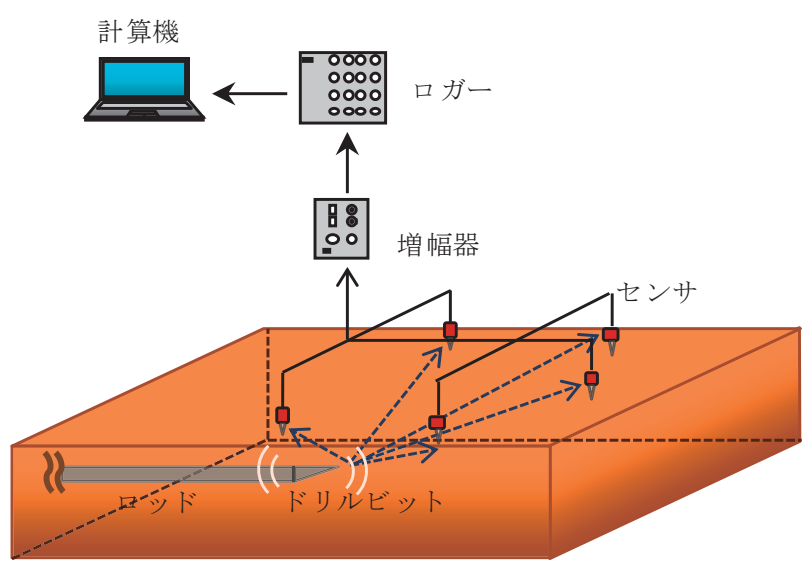

図-3 実験時のシステム構成 
ロによって生じた弾性波のパワースペクトルを示した ものである. 主な周波数成分が $15 \mathrm{~Hz}$ から $35 \mathrm{~Hz}$ 程度に 分布していることから, 今回利用するジオフォンは計 測に適していることが読み取れる. ジオフォンを用い て計測した波形は震源からの距離に応じて適宜増幅し て記録した．実験時の土壌はほぼ単一の泥層であり， 地表面のみ砂利層である. 図-6にジオフォンの配置 図と震源を示寸。震源は図中 $\times$ 印で示された深さ $1.52 \mathrm{~m}$ の位置である. なお，この震源位置は従来の手 法である電磁波法を用いて計測したものである.

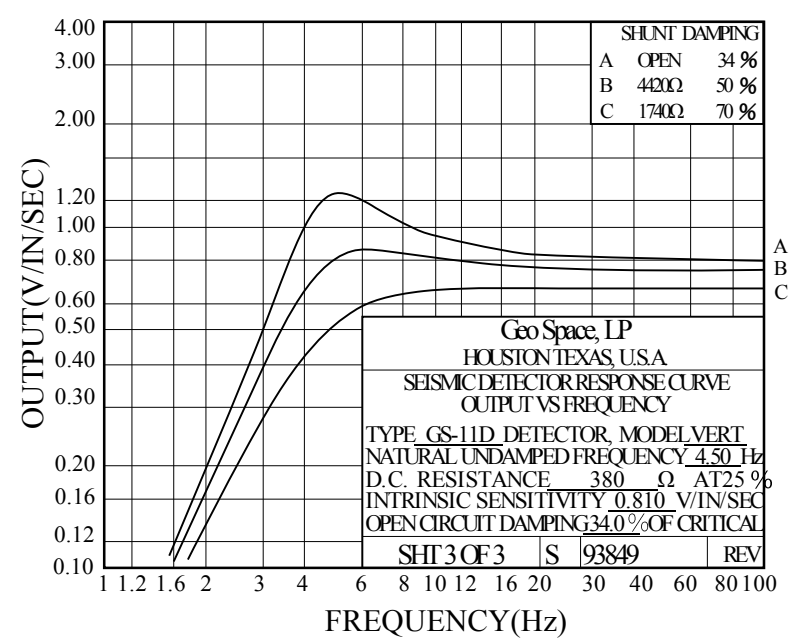

図-4 ジオフォン感度の周波数特性

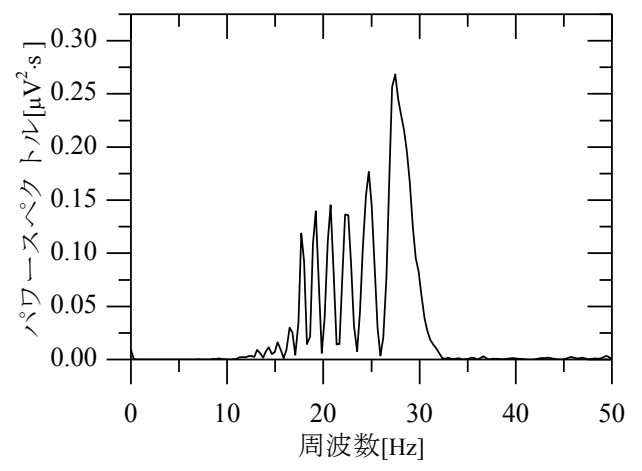

図-5 バイブロのパワースペクトル

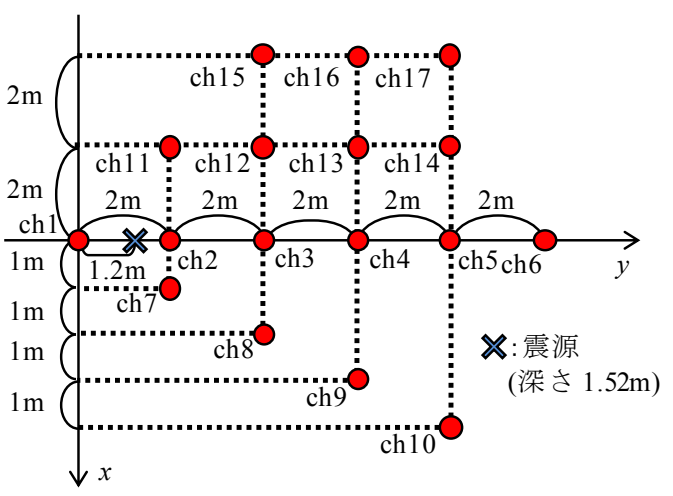

図-6 ジオフォンの配置と震源位置

\section{2 バイブロを用いた計測実験の結果}

図一7 はバイブロによって生じた弾性波の計測波形を 示したものである．上から順に(a)Ch2，(b)Ch6，(c)Ch17 の計測波形を示している. なお，各計測波形の 0 秒の夕 イミングはCh2 で弾性波の到達を検知したタイミングで ある。これは，2 節計測原理で触れたように，弾性波の 発生タイミングを検知寸ることが困難であるためであ る. 図一 6 より, Ch2 に位置するセンサは震源から最も 近い距離にあるセンサであり，このセンサに弾性波が到 達したタイミングで全センサの計測を開始する。 また, Ch6 の計測波形は震源から最も遠いセンサによる計測結 果を示したものであるが，十分大きな $\mathrm{S} / \mathrm{N}$ 比を保ったま ま弾性波がセンサに到達していることが確認できる. Ch17 はドリルビットの進行方向からずれた位置にあり, かつ震源-センサ間距離の大きいCh を示したものである が, Ch6 と同様にバイブロによって生じた弾性波成分を 十分に計測できている事が確認できる. 以上より, バイ ブロによって生じさせた弾性波は非常に強力であり，今 回行った実験領域であれば十分に弾性波が伝播してい る事が確認できる. しかしながら，図一7 に示寸計測波 形は，実体波と表面波の混在した波形である．特に，バ イブロは出力できる弾性波がやや低周波よりであるこ とや出力が大きいことから表面波の影響を大きく受け てしまっていると考えられる.

以降で，各計測波形に対する表面波の影響について検 証した．本実験では，従来の手法である電磁波法を用い て実際の震源位置を予め計測した。これを用いると実際 の震源から各 $\mathrm{Ch}$ までの震源一センサ間距離を計算する ことができる. 図一8 は, 計算した震源一センサ間距離 と各 $\mathrm{Ch}$ での計測波形の正のピークの到達時間の関係を まとめたものである. 縦軸方向に一列に並んでいるプロ ットは，震源一センサ間距離が同じものであり，同一の Ch で計測したデータから抽出した各ピークタイムであ る.また，図中の各シンボルは計測波形のピーク毎に分 けられたものである，ピーク検出を行う際には，高周波 数成分による影響を避けるため $200 \mathrm{~Hz}$ の LPF を適用した 後にピーク検出を行った. なお, 今回用いた LPF は FFT フィルタである. 元波形に FFT を適用後, 不要な周波数 成分を除去し逆 FFT を適用寸ることで, 必要な周波数成 分を含んだ波形を得ることができる．ピーク検出の際に は減衰等の影響で検出できないピークがあったため，そ のようなピークに関してはプロットしていない，図中の 直線は各ピークのプロット毎の近似直線であり, その傾 きの逆数は各ピーク部分の弾性波速度を表す。図一-9 は ピーク毎の弾性波の地中伝播速度を求め, $\mathrm{Ch} 2$ における 各ピークの到達時間との関係をまとめたものである.こ こで, 図-10 は, Ch2 における計測波形のウェーブレッ 卜変換による時間一周波数マップを示したものである. 表面波は周波数が高い程伝播速度が低くなるという特 

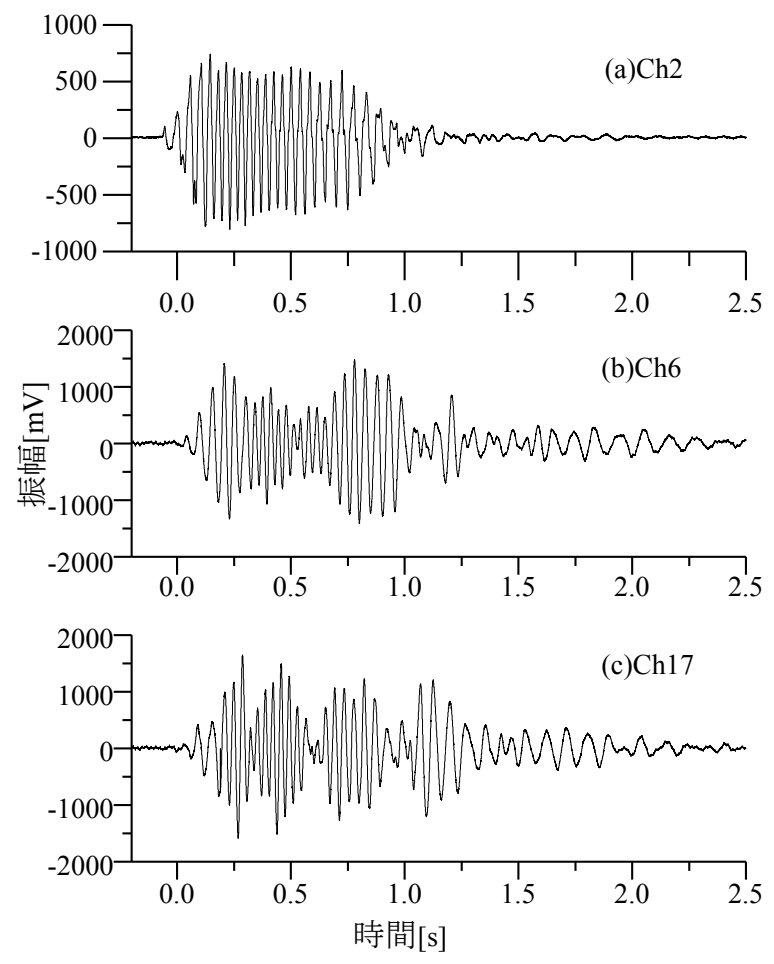

図-7 計測波形

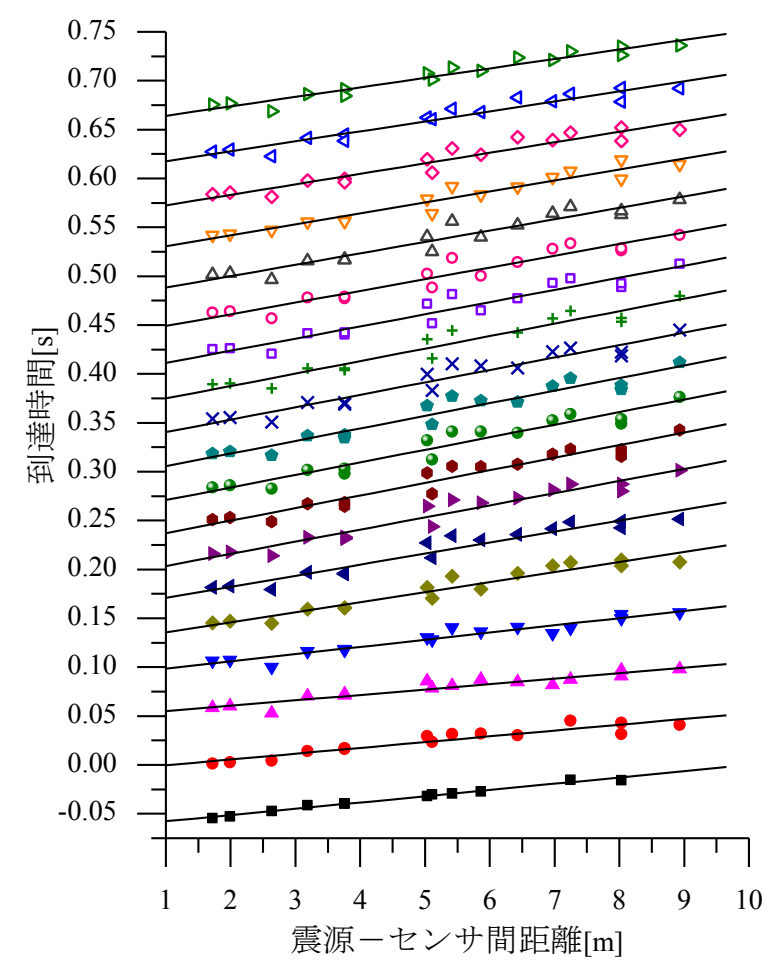

図－8＼cjkstart各センサにおけるピーク到達時間

長 ${ }^{10)}$ を持っているが，表面波の影響が弱く計測波形の 主要成分がドリルビットからの直達波であれば，各ピー クで地中伝播速度に差はほとんど出ないと考えられる。 しかしながら, 図一-9より各ピークでの地中伝播速度は 一定ではなく, また, 図一10 と比較するとバイブロによ る出力周波数の遷移傾向と強く一致している. 以上より,
バイブロによる弾性波の計測波形後半部は表面波の影 響を強く受けてしまっていると言える，次節では，本実 験の計測結果を用いて三次元位置推定を試みるが，表面 波の影響から波形後半部に関しては単純に相互相関等 を用いた解析は行うことができない，そこで，各 Chで の第 1 ピークの時間差を取得することで位置推定を試み る.

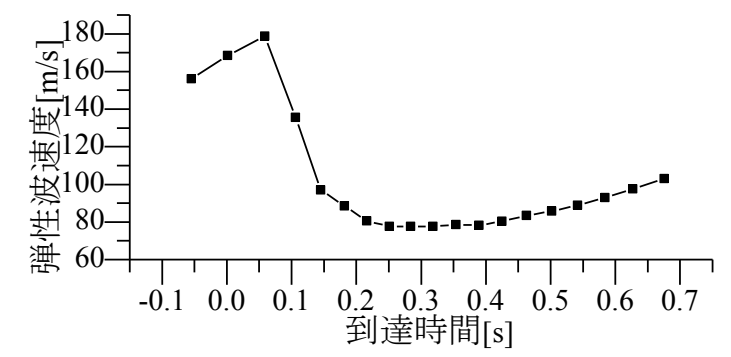

図－9＼cjkstart各ピークの地中伝播速度

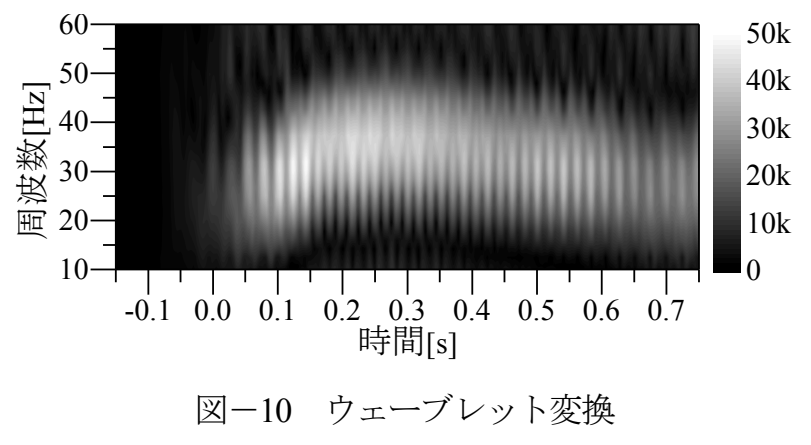

\section{3 第 1 ピーク時間による到達時間差解析}

3.2 節より,バイブロによって生じさせた弾性波には, 計測波形の後半部に表面波の影響を強く受けてしまっ ていることが確認できた， そこで，各 $\mathrm{Ch}$ での計測波 形の第 1 ピークの時間差を取ることで弾性波の到達時 間差の解析を行った. 各 Ch の第 1 ピークの検出時に は 3.2 節と同様に $200 \mathrm{~Hz}$ の LPF 適用後にピーク検出を 行った. なお, 単純にピーク検出を行う場合第 1 ピー クであるという判断が非常に困難であると考えられる が，本実験では震源の位置が予めわかっていることか ら, 図-8のように他 Ch との整合性を考慮することで 検出したピークが第 1 ピークであるという判断は容易 に行うことが可能である. この手法は, 実際の計測時 にもほぼ同様に利用できると予想される. 実際の計測 時に $1 \mathrm{~m}$ 掘進する毎に計測を行う事を考えた場合, ド リルビット先端の位置は 4.1 節(2)項で詳しく示寸が半 径 $1 \mathrm{~m}$ 程度の範囲内に限る事が可能である. これに対 し，ピークを一つ取り間違えるとバイブロの場合少な くとも到達時間に 0.04 秒程度の誤差, つまり距離にし て $4 \mathrm{~m}$ 程度の誤差が生じる事になり他 $\mathrm{Ch}$ との整合性が 取れなくなる.このことから検出したピークは第 1 ピ 一クでないと判断することが可能であると考えられる. 表一2 に示寸のが以上の手法により求められた各 $\mathrm{Ch}$ での計測波形の第 1 ピーク時間をまとめたものである. 
横線で示される $\mathrm{Ch}$ では明確な第 1 ピークを得ること ができなかった. 4 節では表一2で示寸データを用いて 位置推定を試みる.

表一2 計測波形の第 1 ピーク到達時間

\begin{tabular}{c|ccc|c}
\hline $\mathrm{Ch}$ & 到達時間差(s) & & $\mathrm{Ch}$ & 到達時間差(s) \\
\hline 2 & -0.05444 & & 10 & -0.01565 \\
3 & -0.04125 & & 11 & -0.04744 \\
4 & -0.03185 & & 12 & -0.03965 \\
5 & - & & 13 & -0.02925 \\
6 & - & & 14 & -0.01525 \\
7 & -0.05304 & & 15 & -0.03025 \\
8 & -0.03945 & & 16 & - \\
9 & -0.02745 & & 17 & - \\
\hline
\end{tabular}

\section{4 インバージョンによる位置推定}

\section{1 インバージョン手法}

\section{(1) インバージョンの概要}

本研究では推定対象が地中のドリルビット位置であ り，推定に利用する計測対象として地中を伝播する弾性 波を用いる. 従って, 地中の層構造や岩石等の地盤中の 不確定な要素の影響を強く受けてしまう。そのため，2 節の測定原理で示したように最小限のセンサ個数であ る5つのセンサのみで幾何学的な計算からドリルビット の位置推定を行うと推定結果に大きな誤差を含んでし まう，そこで，3 節の実験で計測した多数のセンサの計 測結果に対して，インバージョンを適用することでドリ ルビットの位置推定を行った. 以下にインバージョンに よる位置推定手法の手順を示す.

本研究で用いるインバージョンでは, 様々な震源位置 と弾性波速度を仮定し(次項参照), 各仮定值からシミュ レーションによって到達時間差を計算する. 具体的な計 算手法については 3 項で示すが，この到達時間差と実測 值との合致度合いを比較し, 最も合致度の高かった仮定 值を推定結果とすることで位置推定を行う。位置推定の 簡単な流れは以下の通りである。まず, 震源位置を仮定 し, 各センサとの震源一センサ間距離を計算する. 次に, 2 節と同様に計測現場一帯で層モデルが単一であると考 え, 地盤中の弾性波速度を仮定することで震源から各セ ンサまでの弾性波の到達時間を計算することができる. この結果と実測データとで比較を行い, 仮定した震源, 及び弾性波速度が実際の震源, 速度とどの程度合致して いるかの指標を計算する。 この指標を，全仮定值に対し て計算し，その值が最も大きくなった仮定位置がドリル ビット位置の推定結果となる.

\section{(2) 震源位置と弾性波速度の仮定}

HDD 工法においては，重機から延ばしたロッドの前
進距離を計測することで，ある期間にドリルビットの先 端がどの程度前進したかを知ることができる，そこで， 本研究で用いるインバージョンにおいては，ドリルビッ 卜先端の移動前の位置が既知であり，そこから一定距離 前進した場合にどの位置にドリルビットが移動したか を推定する。図一11 は HDD 工法における推定対象領域 の絞り込久モデルを示したものである. 上記の状況下で は，ドリルビットの仮定位置は，元位置を中心とし，移 動距離を半径とする球面上に絞り込むことができる.さ らに，HDD 工法ではロッドの方向転換に制限があるた め, 球面の中でもドリルビット前方の領域に絞り込むこ とができる. 本研究では，以上のようにドリルビットが 存在し得る領域を絞り込んだ上でインバージョンによ る位置推定を行った. 図一11 中の部分球面が絞り込まれ た推定対象領域の概形を示したものである.この領域内 で以下の方法で震源位置, 及び弾性波速度の仮定值を設 定する. 震源位置の仮定值は $R_{1}$ 及び $R_{2}$ の 2 つのパラメ ータを用いて指定する. $R_{1}$ はドリルビットの進行方向に 対して仰角方向の角度であり, $R_{2}$ は進行方向に対して回 転方向角度である. 本研究では各パラメータの領域を以 下のように設定し，刻み幅はそれぞれ 10 で変化させた。

$$
0^{\circ} \leq R_{1} \leq 70^{\circ}, 0^{\circ} \leq R_{2}<360^{\circ}
$$

合致度の計算を行う際には，上記のパラメータから仮 定位置 $(x a, y a, z a)$ を算出して利用する. 元位置を $\left(x_{0}, y_{0}, z_{0}\right)$, 移動距離を $M$ とすると仮定位置はそれぞれ以下の式で 表すことができる.

$$
\left\{\begin{array}{l}
x a=x_{0}+M \sin R_{1} \sin R_{2} \\
y a=y_{0}+M \cos R_{1} \\
z a=z_{0}+M \sin R_{1} \cos R_{2}
\end{array} \cdots(4)\right.
$$

また, 仮定速度 $v a$ の設定領域は十分広く取り, 刻み 幅は $10 \mathrm{~m} / \mathrm{s}$ で変化させた. 本研究で行ったインバージ ヨンでは, $R_{1}, R_{2}, v a$ の全組み合わせに対して, 次項 で示寸合致度の計算を行い各仮定值と実測值との合致 度合いの最も高い仮定值を推定結果とした.

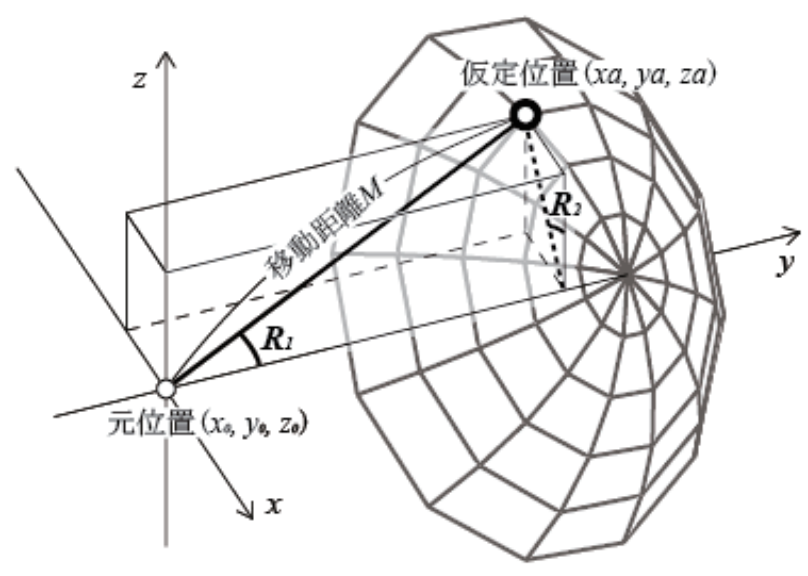

図-11 位置推定領域の絞り込みモデル 


\section{(3) 合致度の計算}

図－12 は合致度計算のフローチャートを示したも のである. 以下, 図-12 に沿って合致度計算手法を示 す. 図-13 は仮定值と実測值の偏差を計算する際の概 念図を示したものである. 眓中の $\mathrm{n}$ は Ch を示してお り， $a_{i j}$, 及び $b_{i j}$ はそれぞれ Ch $i$ と Chj の仮定值から算 出した到達時間差，及び実測值から算出した到達時間 差を示している. なお，実際の計測時には地盤中の不 確定要素の影響や減衰により第 1 ピークが得られない Ch も存在する. 本研究においては，表一中の Ch 5, 6, 16, 17 が第 1 ピークの得られなかった Ch であり, 位置 推定にはこれらの Ch を除いた 12 個の Chによって計 測した波形の到達時間を利用した。

初めに，実測值に関して弾性波のセンサへの到達時 間差を計算する.これは各 $\mathrm{Ch}$ の計測波形の正方向の 第 1 ピークの時間差を取ったものであり, 図一 13 中の $b_{i j}$ に相当するものである. この值は全仮定值における 合致度の計算で利用する。

ここからの処理は全仮定值に対して行う処理である. 最初に震源位置, 及び弾性波速度を仮定する。これは 2 項で示した方法で行う．2 項と同様に仮定位置は( $x a$, $y a, z a)$, 仮定速度は $v a$ で表記する。この仮定值を利用 して震源から各センサまでの距離を計算する. Ch $i(i=1,2,3, ・ ・ 17 \quad ※ 1,5,6,16,17$ は除く $)$ のセンサの位 置を $\left(x s_{i}, y s_{i}, z s_{i}\right)$ とすると震源一センサ $(\mathrm{Ch} i)$ 間距離 $L_{i}$ は 以下の式(5)で表される.

$$
L_{i}=\sqrt{\left(x s_{i}-x a\right)^{2}+\left(y s_{i}-y a\right)^{2}+\left(z s_{i}-z a\right)^{2}}
$$

これと, 仮定速度 $v a$ から Ch $i$ までの弾性波の到達時 間 $T_{i}$ を式(6)で算出することができる.

$$
T_{i}=\frac{L_{i}}{v_{i}} \cdot \cdots(6)
$$

よって, Ch $i$ と Ch $j$ の到達時間差 $a_{i j}$ は式(7)で表される.

$$
a_{i j}=T_{i}-T_{j} \cdot \cdot(7)
$$

よって, 仮定值から求めた到達時間差と実測值の到達 時間差の偏差は $a_{i j}-b_{i j}$ で与えられる. これを $D_{i j}$ とし到 達時間差の組み合わせの数を $N$ とすると, 平均 $A$ 及び 標準偏差 $S$ はそれぞれ，以下の式(8), (9)で表される.

$$
\begin{gathered}
A=\frac{\sum D_{i j}}{N} \cdot \cdots(8) \\
S=\sqrt{\frac{\sum D_{i j}^{2}}{N}-A^{2} \cdot \cdots(9)}
\end{gathered}
$$

ここで, 実測值と最も合致していると考えられるのは, 平均, 標準偏差の双方が 0 になる場合である.つまり, 仮定データの合致度は平均が 0 に近く, また標準偏差 が小さいほど大きくなるようにすればよい. そこで,

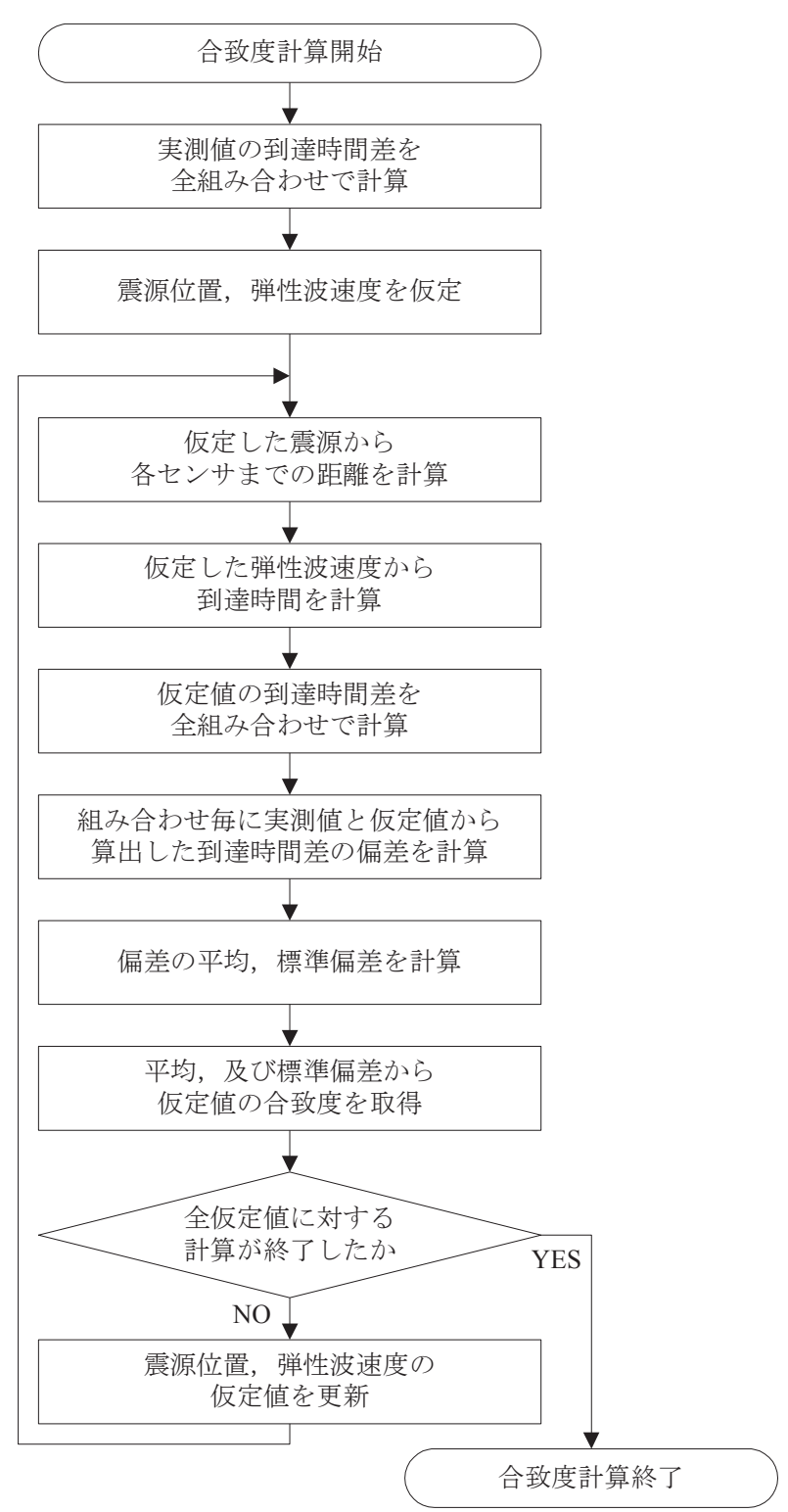

困-12 合致度計算のフローチャート

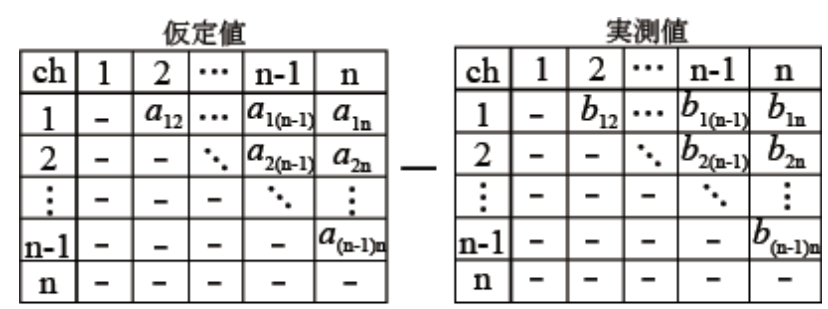

偏差

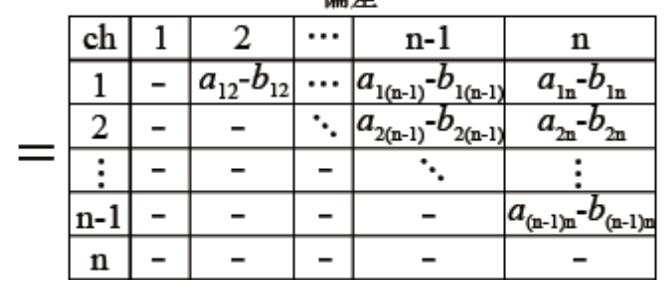

図-13 偏差計算の概念図 
今回は求めた平均と標準偏差から正規分布曲線 $f(x)$ を 描き，その $f(0)$ に対応する值を仮定データの合致度と した.

正規分布曲線 $f(x)$ は，以下のようになる.

$$
f(x)=\frac{1}{\sqrt{2 \pi S^{2}}} \exp \left(-\frac{(x-A)^{2}}{2 S^{2}}\right) \cdots
$$

よって, 合致度は式(10)で算出される值である.

$$
f(0)=\frac{1}{\sqrt{2 \pi S^{2}}} \exp \left(-\frac{A^{2}}{2 S^{2}}\right) \cdots
$$

以上の方法で一つの仮定值に対する合致度を計算する. これを全仮定值に対して行い, 最も合致度の高い仮定 值を本手法の推定值とする.

なお，平均及び標準偏差算出の際に，(a)算出したす べての偏差を用いる場合と(b)突発的な計測誤差を取 り除くために，偏差の絶対值の大きさが上位 $30 \%$ の のを無視する場合の 2 種類の解析を行った.

\section{2 三次元位置推定}

3 節の実験で得られた実測データに 4.1 節で示した インバージョンを適用し, ドリルビットの三次元位置 推定を試みた。 センサ配置, 及び震源位置は図-6で 示寸通りであるが，本研究で用いるインバージョンで は移動前の元位置, 及び移動距離が必要であるため, 元位置を $x=0 \mathrm{~m}, y=-0.8 \mathrm{~m}, z=1.52 \mathrm{~m}$ とし, 移動距離を $2 \mathrm{~m}$ とした. バイブロによる弾性波の計測波形から，(a), (b)の各手法を用いて位置推定を行った結果, 最も合致 度の高かった仮定值を示寸。

（a）全計測データを用いた場合 $x=0.36[\mathrm{~m}], y=0.23[\mathrm{~m}], z=-0.16[\mathrm{~m}], v=170[\mathrm{~m} / \mathrm{s}]$

$(0.36[\mathrm{~m}])(-0.97[\mathrm{~m}])(-1.68[\mathrm{~m}])$

(b) 上位 $30 \%$ のデータを除いた場合

$$
x=0.18[\mathrm{~m}], y=0.97[\mathrm{~m}], z=0.60[\mathrm{~m}], v=170[\mathrm{~m} / \mathrm{s}]
$$

$(0.18[\mathrm{~m}])(-0.23[\mathrm{~m}])(-0.92[\mathrm{~m}])$

また, 図-14, 図-15 は上記(a), (b)における位置推 定の結果として得られた各仮定位置の合致度を, 弾性波 速度が $170 \mathrm{~m} / \mathrm{s}$ の場合において輝度值表示したものであ る. 図中の部分球面は 4.1 節(2)項で示した絞り込みによ って得られた推定対象領域である. 白い部分程仮定値と 実測值との合致度が高い事を示している. また，図中の ○印は実際の震源位置を示したものであり，×印は最良 の合致度が得られた仮定位置を示している. (a) と(b)を比 較すると, 全計測データを用いた場合に比べ, 偏差の大 きいデータを除いた場合の方が，推定精度が向上してい る事が確認できる.

\section{5 結言}

本研究では, 弾性波の入力手法としてバイブロを用い た実験を行い，その計測結果から震源位置の三次元位置 推定を試みた。

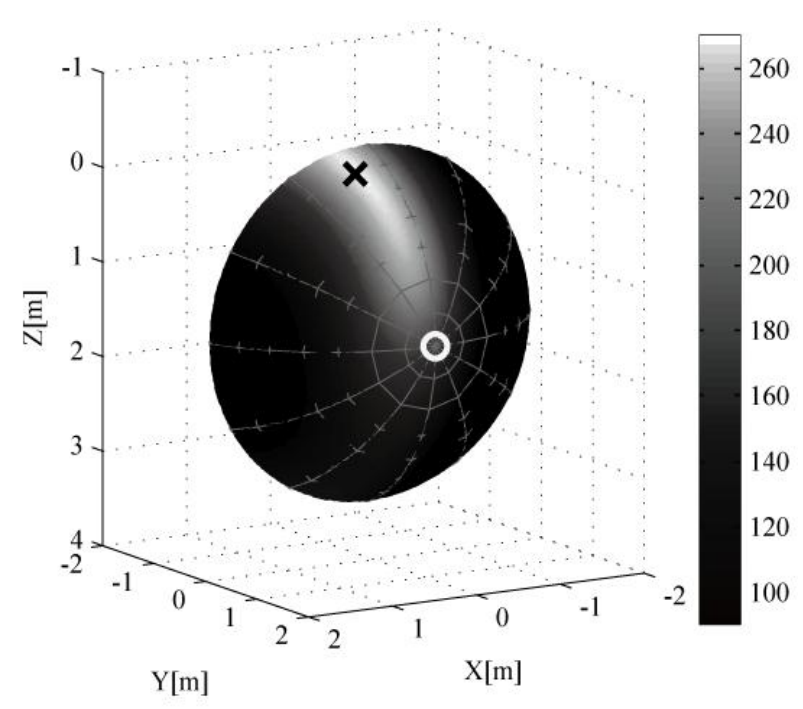

図一14 バイブロによる位置推定(a)

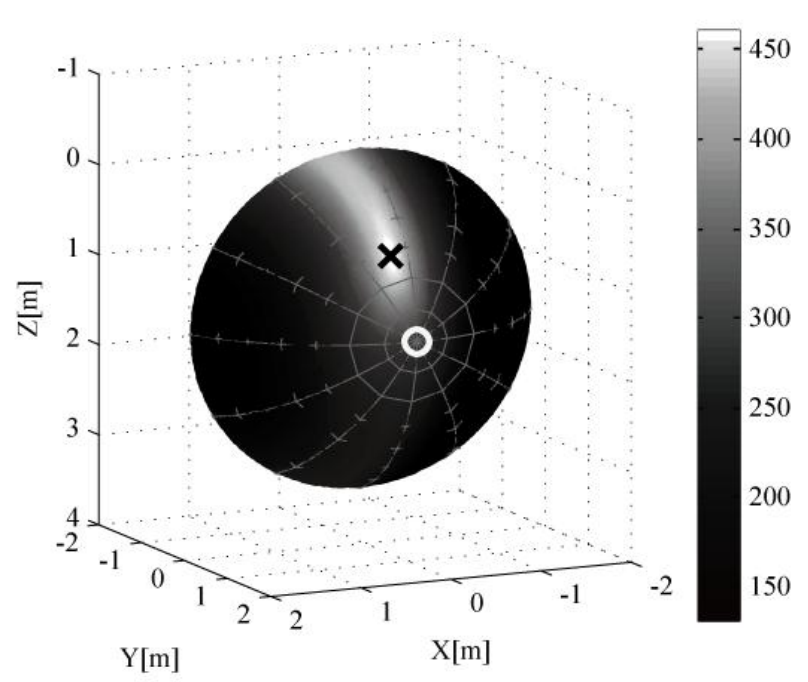

図-15 バイブロによる位置推定(b)

本実験では，HDD 工法に用いる重機に予め備え付け られているバイブロを用いて生じさせた弾性波を，地表 面に設置した複数のジオフォンを用いて計測した. 今回 の実験では, 震源-センサ間距離は最大 $10 \mathrm{~m}$ 程度の範囲 で実験を行ったが，バイブロによって入力された弾性波 は設置した全てのセンサで十分に計測することができ た.このことから, バイブロでは, 非常に大きな弾性波 を出力することが可能であり, センサの設置範囲を広く することで, さらに広範囲での位置推定を行えることが 期待できる.

また, 実験によって得られた計測波形から到達時間差 を取得し，インバージョンを用いて位置推定を行った。 計測したデータから岩石等の地盤中の不明確な要素の 影響を大きく受けているChを取り除くことができれば, 位置推定を行える可能性があることがわかった. しかし ながら, 精度に関しては実用といら観点では不十分であ り, 本研究で得られた結果では, 偏差の大きいものを取 
り除いた場合であっても $0.9 \mathrm{~m}$ 程度の誤差を含んでいた. これは, 従来の電磁波法の推定精度が $0.1 \mathrm{~m}$ 程度に収ま っていることと比較しても，決していいものとは言えな い，そのため，本手法を実用的なものとするためには， 今後の精度向上が必須であるが, 解析手法の改善により 推定精度の向上も見られたことから，バイブロによって 生じさせた弾性波による位置推定を実現する可能性は 十分に示すことができた.

今後の精度向上のための具体策の一つとしては, 複数 回の計測結果の利用が挙げられる。これは，地中の不確 定要素に対する而性を強くするためである. 今回の実験 では，1回の計測結果から位置推定を行っているが，セ ンサ数の増加や同一地点での複数回計測を行う事で不 確定要素の影響を受けにくいシステムを構筑すること ができると考えられる．また，実際に HDD 工法を施工 する際には，ドリルビットが徐々に進行していくため, 掘進に伴って計測を繰り返し行い, 現在の位置に到達す るまでに計測した複数の計測結果を統合することで，ド リルビットの進行と共に徐々に位置推定精度が向上し ていくようなシステムの構築が可能になると考えてい る.

\section{参考文献}

1) L. Tao, T. Takashi, T. Watanabe, and S. Motooka: Jpn. J. Appl. Phys. 38 (1999) 3148.

2) Y. Matsuo, L. Tao, T. Watanabe, and S. Motooka: Jpn. J. Appl. Phys. 41 (2002) 3539.

3) L. Tao and S. Motooka: Jpn. J. Appl. Phys. 46 (2007) 4589.

4) M. Moriya, T. Okamura, T. Sugimoto, T. Shirakawa, and K. Nakamura: Jpn. J. Appl. Phys. 42 (2003) 2929.

5) Ryo Toh and Seiichi Motooka: Jpn. J. Appl. Phys. 49 (2010) $07 \mathrm{HC} 16$

6) 河宜成、川村洋平、蒲原章裕、水谷幸一、大川浩一: 表面波の最大減衰点を利用した埋設物検知、資源素材 学会平成 19 年秋大会、名古屋、pp.271-272、2007

7) T. Sugimoto, N. Yoshida, and M. Okujima: Jpn. J. Appl. Phys. 38(1999) 3161.

8) T. Shirakawa and T. Sugimoto: Proc. Symp. Ultrasonic Electronics, 2005, p. 183.

9) Hiraku Kawasai and Tsuneyoshi Sugimoto: Jpn. J. Appl. Phys. 48 (2009) 07GC08

10) T.レイ、T.C.ウォレス : 地震学 上巻、古今書店 